ZBIGNIEW RUDNICKI

ORCID 0000-0002-5238-0100

SŁAWOMIR FUTYMA

ORCID 0000-0002-8495-9176

Uniwersytet im. Adama Mickiewicza

$w$ Poznaniu

\title{
O DEGRADACJI PEDAGOGIKI \\ I KONIECZNOŚCI SIĘGANIA DO ŹRÓDEŁ. NA MARGINESIE OSTATNIEGO SEMINARIUM - KOLOKWIUM TORUŃSKIE
}

\begin{abstract}
AвSTRACt. Rudnicki Zbigniew, Futyma Sławomir, O degradacji pedagogiki i konieczności sięgania do źródeł. Na marginesie ostatniego seminarium - kolokwium torunskie [About the Degradation of Pedagogy and the Need to Refer to Sources. On the Sidelines of the Last Seminar - the Torun Colloquium]. Studia Edukacyjne nr 59, 2020, Poznań 2020, pp. 17-29. Adam Mickiewicz University Press. ISSN 1233-6688. DOI: $10.14746 /$ se.2020.59.2

In 2019, one of the publishing houses published a book by Professor Aleksander Nalaskowski entitled: Kwieciński The Last Thursday Seminar. This publication is a record of a conversation between two important representatives of Polish science. It can become an inspiration for a change in Polish pedagogy. Professors Aleksander Nalaskowski and Zbigniew Kwieciński formulate a diagnosis of its current state and indicate new directions of development of this socially important scientific discipline. Interesting for the future functioning of this discipline seems to be the foundation of decency and quot; love and quot; understood as unconditional kindness, which is a constitutive feature of humanity.
\end{abstract}

Key words: pedagogy, philosophy of education, sociology of education, humanities, social sciences, sources, dialogue

\section{Prima verba}

W 2019 roku nakładem jednego z wydawnictw ukazała się książka profesora Aleksandra Nalaskowskiego, zatytułowana: Kwieciński. Ostatnie Seminarium Czwartkowe. Jest to pozycja, której żaden pedagog nie może po- 
minąć. Książka ta, a właściwie książeczka, stanowi zapis rozmowy dwóch istotnych dla polskiej nauki jej przedstawicieli. Czując się związani intelektualnie i historycznie $\mathrm{z}$ obydwoma profesorami, będąc nawet (w różnym stopniu) ich uczniami, z uwagą przysłuchujemy się temu dialogowi. Postępując dalej, pragniemy nawiązać rozmowę na zasadzie interwału, który oznacza odległość między dwoma dźwiękami „o różnej wysokości, ale też współbrzmiącymi"1.

Torun ma piękne tradycje prowadzenia debat pomiędzy ludźmi o różnych przekonaniach i jednocześnie usilnie poszukujących porozumienia, jedności i pokoju. Najdoskonalszym tego przykładem, będącym do dziś wzorem do naśladowania, jest Colloquium Charitativum. Spotkanie, które odbyło się w 1645 roku z inicjatywy króla Władysława IV, z udziałem teologów katolickich, luterańskich i kalwińskich, którzy mimo różnic doktrynalnych usilnie poszukiwali zgody wzmacniającej troskę o pielęgnowanie braterstwa (haritatioun od łac. Caritas - miłość) i zachowanie pokoju. Jak możemy przeczytać:

Treścią rozmowy miało być bowiem ustalenie tego co łączy, zbadanie tego co wątpliwe, oraz przedyskutowanie tych rzeczy, które wydają się być sprzeczne z Pismem Świętym i świadectwem pierwotnego Kościoła².

To szczególne spotkanie zostało poprzedzone licznymi konsultacjami, przeprowadzanymi w celu jak najstaranniejszego przygotowania. Instrukcja królewska zalecała, aby nie stosować określenia dysputa (disputare - badać, spierać się), ponieważ nie chodziło o zwołanie „zgromadzenia dysputujących", lecz stworzenie warunków do pełnej życzliwości rozmowy. Przed rozpoczęciem tego spotkania apelowano, aby:

(...) odrzucić wszelkie uprzedzenia, powstrzymać się od gwałtownych słów, od wzajemnego obrażania się, uszczypliwości czy też szyderstwa. Sposób prowadzenia spraw miał być podyktowany uczuciem szczerego, wzajemnego braterstwa, prawdziwej chrześcijańskiej miłości ${ }^{3}$,

stąd nawiązanie to tego szczególnego wydarzenia, którego idea przyświeca rozmowie dwóch wybitnych współczesnych polskich pedagogów. Wartością dodaną tejże rozmowy stała się bardzo oryginalna publikacja, której ukazanie należy koniecznie zauważyć. Oto, mamy w polskiej literaturze pedagogicznej dzieło, które nie ma sobie (w ostatnich czasach) podobnego.

\footnotetext{
${ }^{1}$ J. Habela, Stowniczek muzyczny, Kraków 1977, s. 82.

2 E. Piszcz, Collegium Charitatioum, Znak, 1966, 11(150), s. 1490.

3 Tamże, s. 1493.
} 
Szczera rozmowa była impulsem wyzwalającym wymianę myśli dwóch toruńczyków. Każdy z nich posiada bogaty i niekwestionowany dorobek naukowy. Aleksander Nalaskowski już na wstępie zdradza intencję i prezentuje punkt wyjścia. Ta pierwsza wiąże się ze szczerym wyznaniem „chęci odbycia prywatnego, indywidualnego seminarium”. Wypada zapytać: po co? By uzyskać odpowiedź: „Bo w końcu od kogo mają się profesorowie uczyć”. Po takim dictum nie sposób nie dostrzec tutaj najlepszych sokratejskich wzorców dociekania prawdy za pomocą odbywającego się dialogu. Nie jest to dialog $\mathrm{w}$ zdeprawowanej formie, $\mathrm{z}$ jakim mamy często obecnie do czynienia, gdzie zazwyczaj chodzi o retoryczną żonglerkę, która do niczego nie prowadzi. Etymologicznie "dia - logos” to dwa słowa/słowa dwóch. Tutaj bardziej właściwe jest wykorzystanie rdzenia "logos” w polskim znaczeniu jako „sens, racjonalność, nauka"4.

\section{„Łączy nas to szczególne umiłowanie pedagogiki"5}

Rozpoczynając tę niewielką analizę przestrzeni współczesnej pedagogiki na bazie rozmowy Profesorów, możemy na wstępie przywołać wyznanie Aleksandra Nalaskowskiego:

Niemal wszystko nas dzieli: pochodzenie, ideologie, światopogląd, widzenie szkoły i systemu oświaty, język rozpraw, różnica wieku (16 lat), droga życiowa ${ }^{6}$.

Mamy tutaj przykład wzorcowego wręcz spotkania dia - logicznego w rozumieniu spotkania dwóch sensów. Nietrudno zauważyć, że przy różnicach między opisanymi powyżej dyskutantami, zwykle nie z rozmową będziemy mieć do czynienia, ale raczej z rozejściem się z hukiem, przy akompaniamencie wzajemnego pokrzykiwania na siebie. Zygmunt Kubiak sięgając do Aforyzmów Heraklita podkreśla, że w sprzecznościach występujących w rzeczywistości można dostrzec ukryty porządek:

To co rozbieżne, schodzi się. Z tego, co różne, najpiękniejsza harmonia. Wszystko przez niezgodę powstaje. Nie pojmuję, że przeciwności zgadzają się. Taka jest harmonia przeciwstawnych krańców łuku i liry. Harmonia nie jawna od jawnej mniejsza ${ }^{7}$.

Platońska anamneza (wszelkie poznanie i uczenie na przypominaniu polega) możliwa jest tylko na drodze dialogu, w którym następuje ujawnianie idei i ich powiązań. Platon z zamysłem tak konstruował swoje dialogi, aby

\footnotetext{
${ }^{4}$ M. Korolko, Stownik kultury śródziemnomorskiej w Polsce, Warszawa 2004, s. 361.

${ }^{5}$ A. Nalaskowski, Z. Kwieciński, Ostatnie seminarium, Kraków 2019, s. 6.

${ }^{6}$ Tamże.

7 Z. Kubiak, Literatura Greków i Rzymian, Warszawa 2003, s. 128.
} 
zostały w nich zaprezentowane przeciwieństwa i by móc dokonać weryfikacji tezy poprzez jej konfrontację $z$ antytezą ${ }^{8}$.

Nie jest tak, że książka dokumentuje spotkanie dwóch herosów cierpliwości, którzy chociaż wszystko ich różni, to mimo to zapierają się samych siebie i decydują na prowadzenie dialogu. A. Nalaskowski w swojej książce: Ortodoksja $i$ chaos wspominał o konieczności śmiałego prezentowania, ścierania się odmiennych sposobów myślenia, różnych zapatrywań, sprzecznych podejść. Bo:

Tekst musi prowokować, inaczej nie spełnia swojej funkcji. Powinien prowokować do myślenia, niezgody, zajadłej bądź łagodnej polemiki, rewolucji, krystalizowania się własnych poglądów etc. ${ }^{9}$

Tylko w wyniku polaryzacji może wydobyć się nowa energia. Środowiska naukowe mimo oficjalnych deklaracji „pięknego różnienia się” zwykle skrzętnie unikają takich sytuacji, które jeśli występują, odbierane są jako ataki personalne i brak ogłady. Efektem takiego działania, jak podkreśla A. Nalaskowski:

Pedagogiczna poprawność stała się plagą pedagogiki i skutecznym hamulcem jej rozwoju ${ }^{10}$.

\section{„Maszynka do siekania informacji"11}

Tym co łączyło był wzajemny szacunek (mimo różnic ideowych), umiłowanie pedagogiki jako nauki oraz umiłowanie Polski. Ale obecnie już nikt nie chce czerpać doświadczenia z przeszłości. Współczesność nie potrafi uczyć się na błędach innych, ale przyznaje się powszechnie człowiekowi prawo do wpuszczenia się w kanały odwiecznych, tych samych błędów. Stwierdzenie, że nie ma odwrotu, że się staczamy, to przyznać się do tego, że spora część spomiędzy nas powinna zająć odpowiednie miejsce w zakładach psychiatrycznych, gdyż szara substancja znacznie się już rozłożyła.

Paradygmaty naszego czasu, jakimi stały się intelektualizacja i racjonalizacja, nie oznaczają automatycznie, w porównaniu z poprzednimi epokami, wzrostu wiedzy życiowej, ale jedynie wiarę w to, że można wiedzieć wszystko, jeśli tylko się chce. Dla współczesnej nauki nie istnieją (w sensie ontologicznym) nieobliczalne wymiary świata, siły. Nauka, która wcześniej była drogą do Boga, sama stała się bóstwem, ale takim, które nie mówi nic o sensie świata. Nie daje bowiem odpowiedzi na podstawowe pytania: Co powinniśmy robić? Jak tworzyć swoje życie? A funkcjonariusze tejże, jak powiedział

\footnotetext{
${ }^{8}$ P. Kunzman, F-P. Burkard, F. Weidman, Atlas filozofii, Warszawa 1999, s. 41.

9 A. Nalaskowski, Ortodoksja i chaos, Kraków 2013, s. 167.

${ }^{10}$ Tamże.

${ }^{11}$ A. Nalaskowski, Z. Kwieciński, Ostatnie seminarium, s. 11.
} 
wiele lat temu ówczesny rektor Uniwersytetu Jagiellońskiego Prof. Franciszek Ziejka w jednym z głośnych wywiadów:

(...) przed paru laty głośna była autocharakterystyka jednego z profesorów Uniwersytetu Warszawskiego: „jestem dziwką". Czyli: wynajmuję się za pieniądze do innych prac. A uczelnia staje się jedynie gigantyczną fabryką usług intelektualnych. (...). To tragiczny paradoks, że praca naukowa, która winna być prowadzona przede wszystkim $\mathrm{w}$ celu poszukiwania prawdy, staje się (...) drogą do zdobycia dodatkowego zatrudnienia. Został naruszony kanon etyczny obowiązujący w środowisku. Coraz częściej dowiadujemy się o przywłaszczeniu cudzych wyników naukowych, to znów - o bezceremonialnym przejęciu pomysłów badawczych ${ }^{12}$.

Problemy naukowych koncepcji pedagogiki to nieuświadomione dylematy między subiektywistyczną, nienaukową teorią wychowania człowieka, realizowaną dla określonych według antropologicznych wizji celów, a jedynie deskryptywną, nie służącą bezpośrednio wychowaniu, fenomenologią zjawisk wychowawczych, pretendującą do statusu dyscypliny naukowej $\mathrm{w}$ pozytywistycznym rozumieniu tego pojęcia.

O ile w obszarze angielskojęzycznym wydaje się panować przekonanie, że wychowanie jest fenomenem natury psychicznej, społecznej i historycznej, a stąd jego analizą powinny zajmować się psychologia, socjologia, historia, czy filozofia, to na kontynencie europejskim nieustannie powraca spór o pedagogikę naukową. Obecny obraz pedagogiki wyrasta z tradycji neopozytywistycznej i podnoszony jest przede wszystkim przez przedstawicieli tak zwanej pedagogiki empirycznej, co prowadzi obszar jakim ona się zajmuje do intelektualnego zubożenia i totalnego eklektyzmu.

Rozpoczęło się to roszczeniem uwolnienia pedagogiki od filozofii, odrzucenia idei „specyficzności” pedagogiki, przyznawanej jej przez zwolenników uznawania "mieszanego", deskryptywno-normatywnego czy teoretyczno -praktycznego charakteru tej dyscypliny. Odstąpienie od wartościowania zjawisk wychowania na rzecz stwierdzania faktów wychowawczych oraz odejście od tendencji do reformowania praktyki i praktycznego stosowania rezultatów badań miały przyczynić się do sprostania wymaganiom naukowości.

\section{„Byłoby głupotą nie przejść do źródła"13}

Zdarzyło mi się [Z.R.] kiedyś przyłapać samego siebie na tym, że (być może) dla wzmocnienia mojego dobrego samopoczucia próbowałem utwier-

${ }_{12}$ A. Romanowski, Uniwersytet na wolnym rynku. Rozmowa z rektorem UJ, prof. Franciszkiem Ziejka, „Tygodnik Powszechny”, 1999, 41, s. 4.

${ }_{13}$ A. Nalaskowski, Z. Kwieciński, Ostatnie seminarium, s. 5. 
dzić się w przekonaniu, że to, o czym mówię studentom (odniesienia, przywołania, nawiązania, dygresje) w trakcie zajęć akademickich jest dla nich jasne, oczywiste i nie ma potrzeby za każdym razem zaczynać tłumaczenia poczynając od „budowy gwoździa”. Wielokrotnie w takich sytuacjach moje optymistyczne nastawienie do poziomu oświecenia żaków pękało jak mydlana bańka w konfrontacji z rzeczywistością. Razu pewnego w grupie będącej wówczas kilka tygodni przed ukończeniem studiów magisterskich chciałem rozwinąć problem asymetrii występującej w ocenie zbrodni z czasów II wojny światowej dokonanej na Żydach w Jedwabnem (ofiary zapędzone do stodoły zostały żywcem spalone) oraz na Polakach na Kresach Południowo-Wschodnich, między innymi w Hucie Pieniackiej, gdzie również spalono żywcem zagnanych do stodoły ludzi. Wyczuwając intuicyjnie, że sprawa Jedwabnego będzie słuchaczom dobrze znana, uznałem, że wyjaśnienia wymagać będzie raczej mord dokonany na Kresach Wschodnich. Jednak, aby uzyskać potwierdzenie słuszności mojej intuicji, postanowiłem zapytać: „Proszę państwa, co to jest Jedwabne?". Odpowiedzią była cisza. 50 osób milczało "jak grób”. Postanowiłem, aby zachęcić do zabrania głosu kogokolwiek, dać solenne gwarancje, że jeśli odpowiedź nie będzie trafna, odważny ma z mojej strony zapewnienie „nienaruszalności dobrego samopoczucia”. Znalazła się jedna pani, która nieśmiało, półgębkiem wyszeptała: "Jedwabne, to coś takiego delikatnego, miłego w dotyku".

Migawka druga. Również na zajęciach ze studentami ostatniego semestru drugiego stopnia postanowiłem zadać pytanie, na które moim zdaniem studiujący w stolicy Wielkopolski nie powinni mieć problemu z odpowiedzią. Mianowicie zapytałem, czy mogliby wymienić nazwisko jakiegoś wielkiego pedagoga, żyjącego w przeszłości w Wielkopolsce? Na sali dała się słyszeć głucha cisza. Zatem, sformułowałem podpowiedź: „Ten pedagog uważany jest za jednego z najwybitniejszych twórców pedagogiki nowożytnej. Znów cisza, tyle że tylko bardziej kłopotliwa. Kolejna podpowiedź: „Żył prawie trzydzieści lat (z przerwami) w Lesznie, kto to taki?". Teraz już cisza jakby z krypty wzięta. Kolejna podpowiedź: „Napisał między innymi Wielką Dydaktykę oraz Pampaedię". Dalej nic. Pożałowałem tego, że rozpocząłem ten quiz. Bałem się sformułowania kolejnej podpowiedzi. Targany obawami i wątpliwościami jednak powiedziałem: „Na drugie imię miał Amos”. Po tym jedna z pań niepewnie i nieśmiało właściwie nie odpowiedziała, tylko zapytała: „Czy to może chodzi o Komeńskiego?”. Nie mogę powiedzieć, że kamień spadł mi z serca. Bardziej, że poczułem się jak „kamieni kupa”, ruina, rozpad...

Dwa kadry, każdy odnoszący się do jakiegoś fragmentu przeszłości, która przecież ciągle jest w jakiś sposób obecna. Rzeczywistość współczesna 
zawdzięcza swój obecny kształt jakimś przyczynom ${ }^{14}$. To wyraźnie nasuwa potrzebę powrotu do źródeł, do korzeni, do pierwotnych doświadczeń. Bardzo plastycznie przedstawił to Janusz Korczak, posługując się metaforą kopania studni:

Gdy kopiesz studnię, zaczynasz robotę nie od głębokiego dna: poruszasz szeroko zrazu górną warstwę, odrzucasz ziemię, łopata za łopatą, nie wiedząc, co niżej, ile splątanych korzeni, jakie przeszkody i braki, ile uciążliwych zakopanych przez innych i przez ciebie, zapomnianych kamieni i różnych twardych przedmiotów.

Decyzja powzięta, dosyć sił, by zacząć. A w ogóle, czy jest kiedy jaka robota skończona? Spluń w garść. Mocny chwyt łopaty. Śmiało!

Raz, dwa, raz, dwa.

- Boże dopomóż, dziaduniu! Co zamierzasz?

Widzisz przecie. Szukam podziemnych źródeł, czysty, chłodny żywioł wody odgarniam i rozgarniam wspomnienia.

- Pomóc ci?

- O nie, kochanie ty moje, każdy to musi sam. Nikt nie pospieszy z wyręką ani nie zastąpi. Wszystko inne razem, jeśli zaufasz mi jeszcze i nie ważysz lekce, ale tę ostatnią moją robotę - ja sam ${ }^{15}$.

Nie tylko w nauce można dostrzec (z różną siłą) artykułowaną potrzebę powrotu do początków. Odczuwana jest nostalgia za czymś, co zdaje się było gdzieś, kiedyś, a teraz tego nie ma i odczuwa się z tego powodu brak. Celnie zauważył M. Eliade:

Zapomina się, że życie człowieka współczesnego roi się od mitów na w pół zapomnianych, od zdegradowanych hierofanii, od wytartych symboli. Nieustająca desakralizacja człowieka współczesnego wypaczyła treść jego życia duchowego nie niszcząc jednak wzorców jego wyobraźni: W sferach wymakających się kontroli trwa i żyje cała zdegradowana mitologia ${ }^{16}$.

Jeden z tych głosów - upominający się o ład, szczęście, pełnię - ma za sobą wielowiekową tradycję. Mit Wieku Złotego, "rajskiego ogrodu”, "wysp zaczarowanych", ma ciągle pewne miejsce w ludzkiej (pod)świadomości. Archetyp Raju jest stale obecny w przestrzeni ludzkiej tęsknoty za prawdą, dobrem i pięknem. Bronisław Baczko pisze, iż:

(...) wielkie tęsknoty mityczne związane z Rajem przeniknęły całość świata naszej wyobraźni. Opowieść z Księgi Rodzaju jest nośnikiem nadzwyczaj silnego mitu naszej

\footnotetext{
14 Tamże, s. 85.

15 J. Korczak, Pamiętnik, Wrocław 1998, s. 12.

16 M. Eliade, Sacrum - mit - historia, Warszawa 1993, s. 31.
} 
kultury, który w jednej całościowej wizji łączy etos i kosmos oraz ukazuje antropogenezę jako składnik kosmogenezy ${ }^{17}$.

Przeświadczenie o tym, że u początków udziałem wszystkich ludzi było doświadczenie szczęścia, jest mitem uniwersalnym, którego obecności można doszukać się we wszystkich kulturach. Mit Wieku Złotego w tradycji śródziemnomorskiej skrywa przekonanie, że początek jest jako nowość wszystkiego, wolny od tego co z upływającym czasem coraz bardziej wpływało na degenerację rodzaju ludzkiego. Oddalanie się od momentu początkowego coraz głębiej i intensywniej wywołuje psucie rzeczywistości ${ }^{18}$.

Mircea Eliade zwraca uwagę, że w kulturach pierwotnych następowała doroczna celebracja początków. Obrzędowe powtarzanie kosmogonii miało powodować regenerację czasu obecnego poprzez ustanowienie nowego początku. Powrót do początku kończył niejako stary świat i zradzał nowy, wraz z całym przysługującym mu „wyposażeniem” (siłą, nowością) ${ }^{19}$. Tęsknota powrotu do początków, poszukiwanie „historii pierwotnej” jest bardzo żywa wśród elit intelektualnych „nowego świata”.

Pragnienie powrotu do własnych początków, odzyskanie sytuacji pierwotnej oznacza także pragnienie rozpoczęcia wszystkiego od nowa, nostalgię za ziemskim rajem, $\mathrm{w}$ poszukiwaniu, którego przodkowie narodów amerykańskich przepłynęli Ocean Atlantycki ${ }^{20}$.

Inspirujące jest wyznanie Józefa Wittlina, zawarte w przedmowie do trzeciego wydania jego tłumaczenia Odysei Homera, który „tłumaczy się" z kolejnego powrotu do translacji tego dzieła. Napisał:

Przekładanie utworów takich jak Odyseja można przyrównać do pracy pianisty, który przez całe życie dąży do idealnej interpretacji Bacha, Beethovena, Chopina, itd. Gdy w pełni tak zwanej dojrzałości artystycznej wydaje się mu, że osiągnął maksimum tego, na co go stać, i że lepiej już grać nie potrafi, nagle z pierwszą siwizną we włosach, odrywa, że jeszcze mu daleko do upragnionych szczytów.

A kilka wersetów wcześniej ujawnia tajniki swojego warsztatu:

(...) a ja wciąż siedzę i siedzę i grzybieję nad tym samym tekstem. Poprawiam go, wygładzam, szlifuję i nie mogę uznać za ostateczny ${ }^{21}$.

${ }_{17}$ B. Baczko, Hiob, mój przyjaciel. Obietnice szczęścia i nieuchronność zła, Warszawa 2002, s. 143.

${ }_{18}$ D. Śnieżko, Mit wieku złotego w literaturze polskiego renesansu: wzory - warianty - zastosowania, Warszawa 1996, s. 8-9.

${ }_{19}$ M. Eliade, Sacrum - mit - historia, s. 98-101.

${ }^{20}$ M. Eliade, W poszukiwaniu historii i znaczenia religii, Warszawa 1997, s. 126-127.

${ }^{21} \mathrm{~J}$. Wittlin, Przedmowa ttumacza do trzeciego wydania, [w:] Homer, Odyseja, przekł. z greckiego Józefa Wittlina, Warszawa 1982, s. 7. 


\section{"Chodzi o bezwarunkową życzliwość, której obraz dał parokrotnie Jezus" 22}

Ta tęsknota powrotu do początków, poszukiwanie „historii pierwotnej”, która jest żywa wśród elit intelektualnych wydaje się tęsknotą podobną do tej Archimedesa z Syrakuz: „Dajcie mi punkt podparcia, a poruszę Ziemię”. W rozmowie Dwóch Pedagogów wprost dostrzegamy narzędzie, które może stać się kamieniem węgielnym pedagogiki. Pojawia się ono w analogii do uporządkowanej religijnie rzeczywistości, ale dodając jej jeszcze innych sensów, których większość nie dostrzega. Do sensów tych docieramy przez uważną lekturę zapisu rozmowy. Wprost pojawia się tutaj obraz pedagogiki, rozumianej jako ARCHITEKTURA ŻYCZLIWOŚCI. Nie chodzi bynajmniej, tak to rozumiemy, li tylko o przyjazne usposobienie. Zbigniew Kwieciński, kiedy wypowiada się o podstawowych zasadach budowania gmachu pedagogicznego, wymienia przyzwoitość i „miłość”, czyli bezwarunkową życzliwość, która jest konstytutywną cechą człowieczeństwa. To właśnie ta postawa jest właściwym budulcem nauki, to na niej jako esencji humanizmu opiera się tak rozumiana teoria pedagogiczna. Czy chodzi o miłość bliźniego? Z. Kwieciński odpowiada:

Tak, ale może nie absurdalna, np. że ktoś Cię wali bejsbolowym kijem i ty Go kochasz. Takie zachowanie jest niemożliwe, to nie o to tu chodziło, moim zdaniem, ale chodzi o bezwarunkową życzliwość, której obraz dał parokrotnie Jezus, np. przy wejściu do domu Samarytanina ${ }^{23}$.

Wobec tego, tym co w naturalny sposób wydaje się stanowić fundament ARCHITEKTURY ŻYCZLIWOŚCI jest: rozumność, logiczność, abstrakcyjność, świadomość, skuteczność oraz optymalność. A więc: zdolność do wychodzenia „poza”, zdolność do tworzenia poprawnego myślenia, zdolność do dociekania natury rzeczywistości i tworzenia wiedzy, zdolność do kontroli siebie w imię wyższych, bardziej korzystnych celów człowieczeństwa, co jest gwarancją w miarę trwałych, pozytywnych skutków w kontekście istnienia ideałów.

Taka budowla, która u swoich podstaw ma bezwarunkową życzliwość dokonuje krytycznej refleksji eliminującej przekaz, gdzie wcześniej walczyli ze sobą mitologiczni bogowie, a nad ich walką panował jedynie ślepy los. Bo przecież, jeżeli tylko taki wątek będzie podstawą konstruowania i rozumienia świata, staniemy w perspektywie podążania ślepą uliczką. Wtedy ludzie byliby zmuszeni wybierać między „nowoczesnymi bóstwami”. Zatem, świat,

\footnotetext{
${ }^{22}$ A. Nalaskowski, Z. Kwieciński, Ostatnie seminarium, s. 8.

${ }^{23}$ Tamże.
} 
gdzie pojawia się ŻYCZLIWOŚĆ jest charakterystyczny dla innej racjonalności, w której wymaga się częściowej „ofiary rozumu” i oparcia intelektu na Biblijnych przesłankach odraczających prymitywną racjonalność $\mathrm{w}$ jego rozumieniu. Takie działanie spośród całego spektrum nauki charakterystyczne staje się tylko i wyłącznie dla pedagogiki. Bo to właśnie pedagogika, jak twierdzi profesor Zbigniew Kwieciński:

jest bodajże jedyną nauką, która jest zaangażowana na rzecz pewnej wrażliwości. Jej praktyka jest zaangażowana we wspomaganie rozwoju, opiekę nad różnego rodzaju ludźmi o specjalnych potrzebach, czyli niepełnosprawnych czy chorych ${ }^{24}$.

Niestety, człowiek może przekazywać poczucie sensu już tylko w kontaktach prywatnych, dzięki wszechogarniającej poprawności politycznej. Wiele lat temu dostrzegł to M. Weber pisząc:

To jest losem naszych czasów, że wraz z racjonalizacją i instytucjonalizacją, a więc z odczarowaniem świata, ostatnie i najsubtelniejsze wartości przeszły ze sfery publicznej albo do podziemnego królestwa mistycznego życia, albo do braterskiej relacji między jednostkami ${ }^{25}$.

Bezwarunkowa życzliwość może wprowadzić w świat pedagogów „instrumentalistów" sporo zamieszania. Jako że naturalna będzie rezygnacja, a wręcz świadomość tego, że w świecie tej dyscypliny naukowej jest niemożliwością bycie NEUTRALNYM. Neutralność odsłania swoje oblicze jako złudzenie. Jednak w dalszym ciągu niektórym wydaje się, że to „złudzenia” są właśnie najbardziej widocznym elementem działania ludzkiego. Jednak nie da się ukryć, że to złudzenia w głównej mierze są produkowane przez tę dyscyplinę naukową, jaką jest pedagogika. Kategoria: „złudzenie” w języku polskim oznacza (wg Słownika jezyka polskiego): postrzeżenie zmysłowe zniekształcone lub błędne wobec obiektywnej rzeczywistości, wywołane zaburzeniami w działaniu zmysłów lub specyficznymi własnościami postrzeganych rzeczy; zwykle w liczbie mnogiej urojenie, mrzonka, ułuda, fałszywe wyobrażenie o czymś, o kimś.

Złudny postulat neutralności prowadzi do ubezwłasnowolnienia człowieka. Może on wynikać z dążenia mechanizmów biurokratycznych do rozrastania się oraz kontrolowania i ograniczania wszelkich inicjatyw humanizmu osadzonego w kulturze. Ta złudna neutralność, która w istocie staje się bronią ideologiczną, wprost blokuje źródło kultury, co jawnie prowadzi do niesprawiedliwości. Jak podkreślił w rozmowie z prof. Aleksandrem Nalaskowskim prof. Z. Kwieciński:

\footnotetext{
24 Tamże, s. 9.

${ }^{25}$ M. Weber, Wissenschaft als Beruf, Berlin 1975, s. 36.
} 
Niesprawiedliwość jest rzeczywiście pojmowana ideologicznie, bo jak można inaczej pojmować niesprawiedliwość. To nie jest teoria żadna, to jest pewna zasada ideologiczna, takie przekonanie, że jest niesprawiedliwe zablokowanie dostępu do kultury ${ }^{26}$.

Tabela 1

Architektura życzliwości i jej elementy składowe

\begin{tabular}{|c|c|c|}
\hline $\begin{array}{l}\text { SKŁADOWE } \\
\text { ARCHITEK- } \\
\text { TONICZNE }\end{array}$ & $\begin{array}{l}\text { CHARAKTERYSTYKA } \\
\text { ISTOTNYCH } \\
\text { CECH ARCHITEKTURY } \\
\text { ŻYCZLIWOŚCI }\end{array}$ & STAN FAKTYCZNY \\
\hline ROZUMNOŚĆ & $\begin{array}{l}\text { Zdolność do wychodzenia } \\
\text { poza bezpośrednio dostępne } \\
\text { doznania zmysłowe }\end{array}$ & $\begin{array}{l}\text { Pozostanie na poziomie doznań } \\
\text { zmysłowych, brak lub niechęć } \\
\text { wychodzenia poza nie (powierz- } \\
\text { chowność w podejściu do treści } \\
\text { nauczania) }\end{array}$ \\
\hline LOGICZNOŚĆ & $\begin{array}{l}\text { Zdolność do tworzenia po- } \\
\text { prawnego myślenia }\end{array}$ & $\begin{array}{l}\text { Brak elementarnej poprawności } \\
\text { wynikającej z niedostatku posiada- } \\
\text { nia uporządkowanej wiedzy - brak } \\
\text { wiedzy, ignorancja }\end{array}$ \\
\hline $\begin{array}{l}\text { ABSTRAKCYJ- } \\
\text { NOŚĆ }\end{array}$ & $\begin{array}{l}\text { Zdolność do dociekania na- } \\
\text { tury rzeczywistości i tworze- } \\
\text { nia uogólnionej wiedzy }\end{array}$ & $\begin{array}{l}\text { Brak wiedzy, idący w parze z igno- } \\
\text { rancją, prowadzi do zafałszowania } \\
\text { faktycznego stanu rzeczywistości } \\
\text { wraz z brakiem jej ogólnej wizji } \\
\text { oraz niemożnością dotarcia do jej } \\
\text { natury }\end{array}$ \\
\hline $\begin{array}{l}\text { ŚWIADO- } \\
\text { MOŚĆ }\end{array}$ & $\begin{array}{l}\text { Zdolność do kontroli wła- } \\
\text { snych emocji i odruchowych } \\
\text { reakcji w imię wyższych, } \\
\text { bardziej korzystnych dla } \\
\text { człowieka i całego społeczeń- } \\
\text { stwa, celów }\end{array}$ & $\begin{array}{l}\text { Emocje jako podstawowy mecha- } \\
\text { nizm regulujący formułowanie } \\
\text { określonych celów, niekoniecznie } \\
\text { związanych z oczekiwanymi pozy- } \\
\text { tywnymi celami }\end{array}$ \\
\hline $\begin{array}{l}\text { SKUTECZ- } \\
\text { NOŚĆ }\end{array}$ & $\begin{array}{l}\text { W miarę trwały, pozytywny } \\
\text { dla sprawcy skutek, przy } \\
\text { osiągnięciu założonego celu }\end{array}$ & $\begin{array}{l}\text { Nietrwałe, przelotne i nieprzewi- } \\
\text { dywalne skutki podejmowanych } \\
\text { działań, spontaniczność jako cecha } \\
\text { charakterystyczna dla całokształtu } \\
\text { zachowań }\end{array}$ \\
\hline $\begin{array}{l}\text { OPTYMAL- } \\
\text { NOŚĆ }\end{array}$ & $\begin{array}{l}\text { Preferowanie najwyższego } \\
\text { rezultatu podejmowanych } \\
\text { działań (idealizowanie - } \\
\text { optymalizacja) }\end{array}$ & $\begin{array}{l}\text { Rezultaty działań związane z sy- } \\
\text { tuacją „na przetrwanie” - (byle) } \\
\text { jakość }\end{array}$ \\
\hline
\end{tabular}

Na podstawie: M. Lewicka, Czy jesteśmy racjonalni? [w:] Złudzenia, które pozwalają nam żyć. Szkice z psychologii społecznej, red. M. Kofta, T. Szustrowa, Warszawa 1991, s. 15 n.; por. Z. Kwieciński, Tropy - Ślady - Próby. Studia i szkice z pedagogii pogranicza, Poznań - Olsztyn 2000, s. 233.

${ }^{26}$ A. Nalaskowski, Z. Kwieciński, Ostatnie seminarium, s. 35. 


\section{„Ta nasza pedagogika" ${ }^{27}$}

W 1993 roku na konferencji zatytułowanej: „Teorie i ideologie pedagogiczne a strategie reform oświatowych" Zbigniew Kwieciński tak opisał naszą edukacyjną rzeczywistość „wspólnotową”:

Działamy osobno, bez sojuszy. Rozerwane są więzi między nami, a także między władzą a administracją. Znów stoimy przed „dylematem więźnia” i koniecznością powzięcia „strategii kooperacji wbrew naturze”. Musimy współdziałać, aby przetrwać.

\section{I dalej:}

Koncentrujemy się często na partykularnych zadaniach, na krótkoterminowych i najczęściej osobistych lub rodzinnych interesach najlepszego przetrwania katastrofy. Myślimy w kategoriach pasażerów „Titanica”, których zaskoczyła katastrofa, a zarazem świadomość, że dobrze przetrwa tylko niewielu ${ }^{28}$.

Faktem jest, że w dyscyplinie naukowej, jaką stanowi pedagogika pojawił się kryzys. W sytuacji kryzysu człowiek występuje w podwójnej roli: jest jego sprawcą, ofiarą i zarazem jedynym możliwym wybawicielem. Co z tym faktem uczynić? Zaprojektować i zbudować ten gmach uwzględniając źródła, które są marginalizowane. Zatem, jeżeli oprzemy się na twardym gmachu duchowym człowieczeństwa, pojawi się projekt, kwintesencją którego stanie się edukacja, jak to napisał Zbigniew Kwieciński w swojej pracy: Dylematy. Inicjatywy. Przebudzenia:

Edukacja jako ćwiczenie w otwartym dialogu, jako medium, jako składnik „społeczeństwa umawiającego się" jest warunkiem odblokowania rozwoju każdego i wszystkich aż do poziomu moralnego „uniwersalnej etyki mowy”, to jest zdolności do organizowania, wyrażania i obrony systemu wybranych realizowanych wartości moralnych. To jest też edukacja wedle nowego nurtu i humanistyczne wychowanie ${ }^{29}$.

Czytając Ostatnie seminarium, nie mamy wątpliwości, że chodzi o pedagogikę wpisującą się w kategorię pojęciową ekumene. Ekumena - z języka greckiego oikuméne - to według Słownika wyrazów obcych obszar znanego świata zamieszkany przez ludzi; w przeciwieństwie do anekumena, gdzie tereny bezludne i niewykorzystane tworzą ten świat. Perspektywa aktywności intelektualnej pedagoga mogłaby przypominać sytuację rolnika opisywaną przez

27 Tamże, s. 103.

28 Z. Kwieciński, Tropy - Ślady - Próby. Studia i szkice z pedagogii pogranicza, Poznań - Olsztyn 2000, s. 148.

29 Z. Kwieciński, Dylematy. Inicjatywy. Przebudzenia, Wrocław 2011, s. 174. 
R. Guardiniego, gdzie to rolnik, ziemianin, czy wojownik mogli umierać syci życiem, jak biblijny Abraham, gdyż:

wypełnili przebieg swojego życia i ponad to nie pożądają niczego. Mogli więc na swój sposób osiągnąć ziemskie spełnienie, które czerpali z naiwnej jednoznaczności swoich treści życiowych. Inaczej kulturowych! On może być wprawdzie zmęczony życiem, ale nie syty życia w sensie spełnienia jego przebiegu. Jego perfekcjonizm zmierza bowiem w stronę nieograniczoności, podobnie jak perfekcjonizm dóbr kultury. Im bardziej dobra kultury i cele samorealizacji różnicują i multiplikują się, tym mniejsza staje się cząstka, którą jednostką może jako pasywny, przyjmujący, aktywnie jako współtwórca, ogarnąć w ciągu jednego, skończonego życia ${ }^{30}$.

\section{BIBLIOGRAFIA}

Baczko B., Hiob, mój przyjaciel. Obietnice szczęścia i nieuchronność zła, Warszawa 2002.

Eliade M., Sacrum - mit - historia, Warszawa 1993.

Eliade M., W poszukiwaniu historii i znaczenia religii, Warszawa 1997.

Guardini R., Gesammelte Aufsatze zur Religionssoziologie, tom 1, Tubingen 1978.

Habela J., Stowniczek muzyczny, Kraków 1977.

Korczak J., Pamiętnik, Wrocław 1998.

Korolko M., Stownik kultury śródziemnomorskiej w Polsce, Warszawa 2004.

Kubiak Z., Literatura Greków i Rzymian, Warszawa 2003.

Kunzman P., Burkard F-P., Weidman F., Atlas filozofii, Warszawa 1999.

Kwieciński Z., Tropy - Ślady - Próby. Studia i szkice z pedagogii pogranicza, Poznań - Olsztyn 2000.

Kwieciński Z., Dylematy. Inicjatywy. Przebudzenia, Wrocław 2011.

Lewicka M., Czy jesteśmy racjonalni? [w:] Złudzenia, które pozwalaja nam żyć. Szkice z psychologii społecznej, red. M. Kofta, T. Szustrowa, Warszawa 1991.

Nalaskowski A., Ortodoksja i chaos, Kraków 2013.

Nalaskowski A., Pedagogiczne zwierzątko. Fenomen niewiedzy, Kraków 2015.

Nalaskowski A., Kwieciński Z., Ostatnie seminarium, Kraków 2019.

Piszcz E., Collegium Charitativum, Znak, 1966, 11(150).

Romanowski A., Uniwersytet na wolnym rynku. Rozmowa z rektorem UJ, prof. Franciszkiem Ziejka, "Tygodnik Powszechny", 1999, 41.

Śnieżko D., Mit wieku złotego w literaturze polskiego renesansu: wzory - warianty - zastosowania, Warszawa 1996.

Weber M., Wissenschaft als Beruf, Berlin 1975.

Wittlin J., Przedmowa tłumacza do trzeciego wydania, [w:] Homer, Odyseja, przekł. z greckiego Józefa Wittlina, Warszawa 1982.

${ }^{30}$ R. Guardini, Gesammelte Aufsatze zur Religionssoziologie, tom 1, Tubingen 1978, s. 570. 